\title{
Teachers' Perceptions and Use of Information and Communication Technology in Teaching and Learning: Kadjimi Circuit, Kavango West, Namibia
}

\author{
Iyaloo N. Waiganjo \\ The International University of Management, Windhoek, Namibia \\ Email: i.waiganjo@ium.edu.na, inhaitula@gmail.com
}

How to cite this paper: Waiganjo, I.N. (2021) Teachers' Perceptions and Use of Information and Communication Technology in Teaching and Learning: Kadjimi Circuit, Kavango West, Namibia. Open Access Library Journal, 8: e7236.

https://doi.org/10.4236/oalib.1107236

Received: February 10, 2021

Accepted: March 22, 2021

Published: March 25, 2021

Copyright $\odot 2021$ by author(s) and Open Access Library Inc.

This work is licensed under the Creative Commons Attribution International License (CC BY 4.0).

http://creativecommons.org/licenses/by/4.0/

(c) (i) Open Access

\begin{abstract}
The study aimed to describe how secondary teachers in rural arears integrate technology into education and also to gain an insight on their perception and attitudes towards the integration of technology into teaching and learning. This research used a qualitative case study research design, to describe secondary school teachers' viewpoints. Convenient sampling method and Focus Group Discussion were used to collect data from twenty-four (24) teachers in Kandimi Circuit. The study stipulated that the most used technology is computer, because of its multi-functioning aspects. The study also found out that there were challenges such as lack of skills, ICT tools, cell phone usage stigma, just to mention a few. The study shows evidence that most teachers have the right attitudes and positive perceptions on the meaningful use of ICT in teaching and learning, therefore they must be encouraged in using ICT to embrace Namibian education sector. The study also indicated that the majority of teachers in school management have no positivity in integrating technology in teaching and they resist changes. Finally, there was a proposal for a proper ICT training that should be implemented by ICT Champions whom the government has to appoint. The study further established that there is a need to provide all schools with adequate internet access.
\end{abstract}

\section{Subject Areas}

Education

\section{Keywords}

ICT, Education, Secondary Teachers, Teaching and Learning 


\section{Introduction}

\subsection{Background}

Information Communication and Technology (ICT) is becoming increasingly important in our daily lives and in our education system [1]. It provides learners with global innovative opportunities which are suitable for the current industrial revolution which is surrounded by the development of technology. Those are the reasons why many countries' governments now regard the basic skills and concepts of ICT as part of the core of education [2]. These reasons are in line with the Namibian Ministry of Education pedagogy as stated in the National Curriculum for 2010 that a dynamic ICTs infrastructure that can facilitate effective communication, as well as easy access to, and processing and dissemination of information and knowledge, learners are to be able to use their knowledge and skills in their further studies as well as at employment. This study focused on investigating teachers' perceptions on the use of technology in teaching and learning and teachers who are teaching at the secondary level in rural area schools of Namibia.

\subsection{Statement of the Problem}

In the study of evaluating the implementation of the ICT policy for education in rural Namibia school, [3] stated that there is insufficient evidence on how ICT is being implemented in Namibian schools, especially in rural areas. Also according to [4] in their study of the teachers' use and integration of ICT in the teaching of Life Science in two urban high schools in Namibia, little is known about how teachers use ICT to teach subject content and there is very few works of literature in this area. It is therefore that this study will add a scale of data sets to illustrate how ICT is being used in Namibian schools especially in rural schools. Moreover, teachers have to implement ICT into a classroom by merging new technologies and new pedagogies to have a digital classroom-based. [5] in his study "to adapt ICT in schools to assist in the war against poverty and underdevelopment in Namibia", highlighted some of the major barriers that hinder successful ICTs integration by schools, but his study does not include teachers' perception in the use of ICT. The government; through the Ministry of Education needs new pedagogy about the use of ICT in education and the effects of ICT have on teaching and learning in Namibia to motivate for better decision making in the ICT policies. Therefore, it is worthwhile to investigate how rural school teachers use technology in their teaching and their perception towards ICT at the secondary level.

\subsection{Objectives}

The study's main aim was to describe how teachers in the Kadjimi circuit integrate technology in education, their perception and attitudes towards the integration of technology into teaching. This study bears the following specific objectives:

- To gain insight about teachers' viewpoints on how they feel about integration 
of all sorts of technologies into their teaching.

- To gain insights on types the of ICT tools which are available at schools which are being used by teachers in enhancing their teaching and learning.

- To gather data on different ways on how teachers use ICT in the classroom and their reasons for using ICT.

- The last objective was to find out the main challenges faced by secondary teachers in the Kadjimi circuit when integrating ICT in teaching and learning at school.

\subsection{Significance of the Study}

The perception of the use of ICT that was demonstrated by teachers in this study will motivate teachers and student teachers to be integrated technology in their teaching and learning. One of the challenges faced by teachers is the difference in the curriculum which they use in high training institutes and the one used in secondary schools. Therefore, the study will guide high institutions to find better methodologies to train their student teachers on how to integrate ICT in their teaching and learning effectively in all the school subjects. The study provided current knowledge on the use of ICT in the Kavango West region, Namibia at lager and to the decision-makers in the Ministry of Education Art and Culture. This knowledge will enhance decision-makers to make better decisions concerning ICT in education in the region and the rest of the country. The study's findings can also be used to evaluate Namibian Institution of Education Development's (NIED) progress.

\section{Literature Review}

ICT stands for Information and Communication Technology an extended form of Information Technology (IT), which is defined as technologies that provide access to information through telecommunications [6]. While [7] defines ICT as the merging of audio, visual, telephone and computer networks through a link system. [8] Sated that ICT allows people to store, process and transmit information faster and up-to-date data. ICT are the technologies which are used to provide fast communication and huge amount of information from all over the word at once and in the real time.

Because of booming growth, usage of technology in today's world is shoving many teachers to integrate ICT in classrooms. The [9] said that, methods of teaching and learning which uses ICT to support enhancement and optimize the delivering of information is referred to as ICT in education. While [10] said that, teaching and learning do not depend exclusively on the handwritten or printed materials based on ICT. He further stated that there are many rich materials on the internet and knowledge which can be exchanged through, video, audio, the visual presentation just to mention a few. The team from [9] stated that ICT can lead to better-quality student learning and better teaching methods. ICT in education is simply incorporating teaching and learning methodologies and tech- 
nology to have innovative lessons in classroom.

The study conducted by [11] findings' indicated that most of teachers and learners own mobile phones and they used them to access the internet, download education material and applications from the internet using mobile devices, use mobile devices as calculators, access social networking sites, search for definitions of words on mobile, send emails, conduct searches for material, read assignments just to mention a few. Therefore cellphones are highly recommended device to be integrated in teaching and learning because of its portability, easily accessible and multiple functionalities as presented in the findings.

Technology develops and improves the quality of education; it expands learning opportunities and makes education accessible [12]. The whole world is currently connected with the improvement of technology [13]. Therefore when teachers and learners are connected to the technology they are provided with appropriate information that will empower them in and out of the classroom.

\subsection{Barriers towards the Use of ICTs in Teaching and Learning}

Several factors have been pointed out in literature as barriers to ICT integration in teaching and learning, below are the common barriers faced by teachers:

[14] Explored the challenges faced by teachers in integrating ICT into the teaching of reading and writing in some rural and urban primary schools in Namibia. And her study presented that, 100 percent of teachers in rural schools and 40 percent of teachers in urban schools, according to [14], lack proper ICT training and they argued that because of lack of training and guidance, they rarely integrate ICT into their lessons. Besides, the lack of adequate training teachers gets, affects their confidence and comfort level with the use of technology [15]. Training is essential to the integration of ICT in education when teachers lack training leads to the lack of skills.

[16] stated that teachers lacked training in ICT pedagogy due to lack of time to learn and incorporate ICT skills and tools into lessons. When teachers lack skills ICT integration will be unsuccessful.

The study conducted by [17] to assess teachers' perception of integrating ICT in the teaching-learning process in Ethiopia indicated that the majority of teachers are unable to use hardware in the teaching-learning process due to mainly shortage of resources. In Kenya, most of the teachers noted that the ICT resources were not adequate and this was the reason why most of them did not have a chance to use the ICT in classrooms. While in Namibia, [3] implies that in the rural area, basic equipment such as desks and chairs are lacking, and the inconsistent supply of electricity makes it difficult for teachers teach using computers and the Internet. Not only that, there is also lack of ICT equipment such as, hardware and educational software [18].

\subsection{Namibian Teacher's Perceptions of ICT in Education}

Teachers believe that using ICT in schools will improve teaching and learning. 
But when [19] Investigated teachers' perceptions of the use of ICT in Teaching and Learning in Namibian primary education, their finds indicated that teachers can conduct teaching at anytime and anywhere with the use of ICT. Moreover, Namibian Life Science teachers, use ICT in their classrooms to promote collaborative and creative teaching through smart boards connected to e-Learning Management Systems and collaborates with notes that are shared [20]. Teachers in Namibia have expressed interest and willingness to integrate ICT in their teaching and learning situations [18]. Teachers are positive and understand the benefits of incorporate technology in teaching and learning.

\subsection{The Role of Teachers in the Success of Technology-Based Learning}

[21] Recommended that teachers will need access to long-term professional development that focuses on improving their knowledge and application of curricula, instruction, and assessment not just computers. [22] Said that teacher's roles are divided into two tasks. The first one is to plan and provide digital content for learners and the second one is to create a very good relationship between them and their learners. [23] implies that today's teachers to be successful in their career they need to be on the lookout for all technological advances and especially those that have educational potential.

\section{Methodology}

A qualitative research methodology was designed in order to understand the insight phenomena realities for teachers' perception on the use of ICT into their teaching. This study is in a form of a descriptive data which is aimed at gaining insights into the phenomenon under investigation.

The study did not want to generalize its finding but rather quote words of participants because of that it is based on interpretivist paradigm. The research focused on human experience within the context, therefore it focused on one circuit which was Kadjimi and did not wish to generalize the findings; hence a case study was used. The researcher used qualitative method to gain in-depth exploration of the teachers' thoughts, feelings and understandings on the subject [24]. A semi-structured focus group discussion with the participants provided the research with important insight to the educational technology [25]. The qualitative method was chosen because the researcher was interested in the description, understanding, and interpretation of the study, which allowed the researchers to gain an in-depth understanding of the participants' views on the integration of educational technologies in their teaching and learning.

\subsection{Population}

Kadjimi circuit is situated in Kavango West region. Nkurenkuru, which is the capital town of the region, becomes a town in 2013, located 135 Kilometers west of Rundu and is the smallest town in Namibia with an approximate total popula- 
tion of 120,000 people. The region is still under development since it is just 6 years old. In this area, the majority of learners are living in rural areas, where homesteads are made from mud and glass. From the observations, most parents make a living from fishing, cattle farming and cultivating sorghum, mahangu, and maize. Kavango regions (West and East) are situated in the North East of Namibia, and it is indicated with a red solid line and highlighted in what on the map below.

According to the secretary of Kavango West regional directorate of education, "the region has 7 circuits with about 1604 teachers and about 20583 learners. Kadjimi circuits have seven (7) secondary level schools with a population of 245 teachers who are qualified to teach at that level.

\subsection{Sample}

Since the research was based on qualitative nature; a small sampling number was convenient. The researcher used haphazard sampling method to select a sample of 24 secondary teachers out of 118 teachers from 4 out of 7 schools in the circuit. Haphazard (Convenience) sampling is a nonrandom sampling type where the sample is selected on criteria such as such as easy accessibility, geographical proximity, availability at a given time, or the, willingness participants to take part in the study [26]. The research was conducted in the third term where most secondary teachers are busy preparing their senior learners (grade 10 and 12) for a national exam. Also the researcher was instructed by the regional director not to disrupt teaching and learning when conducting the research. Due to these reasons only teachers who were willing and available to partake in the group discussion were convinced sampled.

\subsection{Research Instruments}

Data on the perception of participant was collected using Focus Group Discussions (FGDs). The discussions were used to generate qualitative data from individuals to address the research objectives. The FGD provided a more natural environment, were participants influence and get influenced by one other [27], in this way the study was able to generate data that was relevant and it was able to see the real idea of the use of technologies from participant's perspective.

\subsection{Data Analysis}

The researcher coded data collected and extracted themes from the codes. The data that was recorded on audio was transcribed into a Word document for each FGD with its own Word document. Open coding was used to code data for analysis; this was achieved by reading every word in the documents to discover general themes of which the researcher filtered out and labeled them with the codes that summarized the meanings. Axial coding was relating codes to determine relationships and to make connections between them. Data was refined and concluded in the main theme. 


\section{Results}

The result describes the teacher's viewpoint on the use of technology in teaching. Data was collected from teachers; therefore, Socio-Demographic characteristics. Information from the findings provided the context within types of ICT technologies available at schools and those that are being integrated into classrooms. Followed by a description of insight on how different sorts of technologies are being integrated into education.

\subsection{Findings on Socio-Demographic Characteristics}

Data presented in Table 1, majority of the participants 11 were between the age of 20 to 29 years, 10 of the participants were at the age of 30 to 39 and only 2 participants who above 40 years old. Table 1 shows that 15 male and 9 females participated in the study, 17 participants who were the majority their teaching experience was below 10 years. 5 participants have teaching experience of 10 to 19 years and only 2 who have more above 20 years of teaching experience.

\subsection{Findings on ICT in Education}

\subsubsection{Technology Tools per Participants}

Participants were asked to mention any kind of technology they think of in the ICT integration in teaching and learning including the ones present their schools and the ones they just know from somewhere else. These were the technologies mentioned by the participants: Computer, Projector, Internet, smart phones, Smart board, Videos, Copy machines, Audios/Audio CDs, PowerPoints, Television, Camera, Tape cassette, Cloudpaging, Smart Board, Social Media, Notepad, CDs, Tablets, Speakers, Geogebra App, Games and YouTube.

Table 1. Socio-demographic characteristics $(\mathrm{N}=24)$.

\begin{tabular}{cc}
\hline Characteristics & Frequency (n) \\
\hline Age & 11 \\
$20-29$ & 10 \\
$30-39$ & 2 \\
$40-49$ & \\
Gender & 15 \\
Male & 9 \\
Female & \\
Years of Teaching experience & 17 \\
below 10 & 5 \\
above 20 & 2 \\
\hline
\end{tabular}




\subsubsection{Types of Technologies Available in Schools}

Four schools that were part of the study had different types of technologies, and some schools were equipped with ICT more than the others. At least all schools have some tools of ICT to integrate into their teaching and learning. For the ethical purpose, the study will keep the school's name anomalies.

School $\mathbf{A}$ has a total of 47 computers, 30 in a computer lab, 15 in a library and two laptops for teachers to use. There was internet but at the time of the study, it was not working. The school has three digital cameras, recording audios, and videos on CDs and tapes. "Most of the videos and audios are for geography subject”, said by the participants.

School B has 40 computers, out of 40, 26 are working while 14 computers were broken. There was one overhead projector, one television, 3 photocopy machines and one laptop. There was internet but it was not working during the time of the study.

School $\mathbf{C}$ has an educational application that is having all the subjects' contacts, from games to tests and quizzes. This application is called Cloud paging and it was procured by a company called Cyber power from the USA. This application has been installed on every teacher's computer (those with their own laptops), of which the majority said they have. At the same school, only ten desktop computers where in the computer lab, one projector, a smartboard, television, radio, and one laptop owned by the school.

School D has very few technology tools. The school has one laptop and 10 iPads which were donated to the school few weeks before the study was conducted. The school has internet that was just installed and one printing machine.

\subsubsection{An Ideal Classroom for Today's Teachers}

When teachers were asked to visualize their ideal classroom, 10 out of 24 participants visualized a classroom that has mounted projector, with a smartboard. Participants said that having a projector mounted in class will save their time to look for projects and save time with connecting and setting up a projector. According to one of the participants "I want every classroom to have a smartboard and a projector so that I will not need to be unplugging them". Two participants want a learning management system, which will allow them to upload notes for their learners. They want a system where they will have real-time tests and examinations. "I want a classroom that has computers, where every learner has access to it, every learner having his or her computer", it's a wish of one of the participants who just want all her learners to have computers. One of the participants said he wanted to be sharing his notes with learners via email, therefore he wished for every learner to have an email account.

\subsubsection{Types of Technologies and How Teachers Integrate Them into Their Teaching and Learning \\ 1) YouTube Videos}

"Teachers use technology because it makes learners interactive in the class- 
room, especially when learners watch videos, they enjoy the class", this had been said by one of the participants. In subjects like English where there are literature parts, technologies like videos make it easy for teachers to teach and make learners understand better. When teaching novels, before they start to read storybooks, they make learners to watch a movie of that book on a laptop first, so that when they will start reading the book they already have an idea of the story.

A geography teacher said he downloaded videos with most topics he taught from the internet, Some CDs are already recorded with videos on geography topics he plays them to his learners. The Biology and Science teachers go on the internet and download videos from YouTube which are showing demonstrations of any experiment that they were supposed to be done in class and the school does not have equipment. Being explained by one of the participants:

"There are some topics that are practical in Biology like food test where the demonstration is needed, I go on YouTube to download a video and show it to my learners."

\section{2) Cell (mobile) Phone}

"I use the cellphone to make calls, just to ask a colleague in the other schools to inquire about information." Apart from making calls, phones are used for various reasons. Seven (7) participants have indicated that a cellphone is one of their important technology tools in their teaching work. It had been emphasized by one of the English teacher who said, "In my English class, when I am teaching literature rhymes I usually play songs and poems on my phone, because the phone is handy than radio and laptop". Cellphones are portable than any other technology and accessible, just like what the teacher said. Because of limited technologies at schools, teachers prefer to use cellphones that they will not have to share with other teachers. This was emphasized by a History teacher who said: "I use my phone $90 \%$ of the time, I prepared using my phone because I won't share it with anyone, its mine." Teachers use cellphones as storage devices to store their notes and summaries, as it was said by one of the participants saying:

"I use more often my phone because my entire subject notes are on the phone, I don't write notes on the board, that west time I read notes from my phone and explain. I give the notes to my learners printed on the document."

Some teacher's use the cell phone as a device to search for information on the internet, as it was explained by one of the participants saying that, "I use the phone to search for information, the latest news, and tell my learners on what is happening in the world."

\section{3) Internet}

Participants said that they use the internet to download educational videos from YouTube to research content materials, vocabularies and any information relating to the subject content. The computer teacher explained that: "When computers are connected to the internet I ask my learners to search information 
on the internet, because there are so many things on the internet". And the other one said, "I can't do without the internet and computer, I like searching for new information". To some of the participants, the internet is very important to the participants because the internet is the center of all the information a teacher needs for their teaching.

\section{4) Educational Applications}

Teachers do integrate the educational applications to add more content to their teaching materials. Mathematics teachers used Geogebra and teachers from school C used Cloudpaging. "Geogebra is very wonderful software for Mathematics", said one of the mathematics teachers who integrate it in her teaching and learning. They also said:

"As you can see on the board there is an application Cloudpaging there, it is installed on our laptops, most of the science teachers are having it, all what we do is, go with a laptop, connect the projector and start your class. If you want to give them games you do that, if it's about simulations or doing some experiments it's there, and it looks and feels like it's a real thing."

\section{5) Computers}

About 20 participants indicated that they use computers in one way or another. It had been indicated by teachers early that they use the internet. The internet gets connected to a computer for teachers to research for information. Teachers said they use computers to show videos to their learners. Also, applications (Geogabra and Cloudpaging) are installed in teachers' laptops. For many teachers, computers are the most important tool because of its multiuses in the integration of education than other technologies. A computer is used to store teaching resources as it was emphasized by one teacher "I keep all my notes in a laptop". Some teachers use a computer to type their tests and notes, while others connected a computer to a project to display information on the board. One participant said," Laptop is the most important to me; I type all my notes and test on my laptop. I use it for presentations, to display PowerPoint on the board when I am teaching." Computers are one of the most valuable resources in a classroom because they serve many useful functions for teachers.

\section{6) Printing and scanning machine}

Teachers scan images from textbooks which are difficult to draw on their own. One participant emphasizes how he used it in his science class:

"In my science class I normally scan things that I cannot draw with my own hands and beside, drawing takes time. I insert the drawing on the PowerPoint and then display using a projector".

Printers are common technology used by teachers but they are not considered to be important in teaching and learning by the participants. They help teachers to print out soft copies to hard copies mostly handouts and test papers.

"Instead of me writing a test on the blackboard, I type them on the computer and print them out. I give tests on the printed paper" said one of the participants 
who use a printing machine. Another participant said that: "I print out their summaries and give them a handout". Another participant who uses a printing machined stated that:

"Instead of us wasting time to write on the chalkboard, it's better to give learners printed copies and you will just explain from the handouts."

Teachers use printing machines mostly to print notes and tests as indicated by participants.

\section{7) Projectors}

Four of the participants stated that they integrated projectors in their classrooms to display information (PowerPoints, notes, and Videos) on the board. Teachers also use projectors to get attention from learners. Learners pay more attention and concentrate in class when they view lesson content from the board than paging through a textbook. Additionally, teachers will have control over the classroom. Moreover, textbooks are not enough for every learner, therefore for one textbook to be shared some learners will not pay attention to the teacher. One of the history teachers said:

"In my history class, I use a projector to display information, especially cartoons. If I display cartoons on the board, then I will have all learners' eyes on board and I will be able to see who is following and who is not. Instead of me telling them to look in the textbooks, which are not enough as one textbook is shared among 5 learners and when they share not every learner sees the cartoon".

Also, another participant stated that: "I present my notes on PowerPoints and connect a project on my laptop and display on the board."

\subsubsection{Importance of Integrating Technology into Learning and Teaching}

Teachers imply that they use technology for different reasons and those reasons differ from subjects or personal experience.

\section{1) To save time}

Three teachers built upon one another explanations to describe how technology makes their work easy and save them time from writing on boards. One participant stated that: "technology is good because it enhances teaching and learning and simplifies work." Another said that: "technology saves me from writing on the board, instead of wasting time writing on board I just project PowerPoint presentation". Then the third participant stated that: "Technology saves us time, instead of us wasting time with writing on the chalkboard; it's better to give them printed copies and will just explain from the handout."

\section{2) For learner's exposure}

Learners get exposed to much innovative information from all over the world through the use of the internet and other means of devices. In addition, the internet makes learners stay engaged in the classroom and outside the classroom. This was emphasized by one of the participants: 
"Technology brings the world in the class. Instead of giving examples of Nkurenkuru we will show things that are outside Nkurenkuru on the internet, and we can share with those that are far away like in Europe. In fact, they can go to Europe with technology while they are still in class."

3) To improve interaction and learning efficiency

"When you are playing them a video on YouTube, they (learners) get more excited, and enjoy it', said a participant who uses technology to make learning fun and make her class interactive. Technology enhances learning when used effectively. According to the participants, technology improves learners learning efficiency when they show them videos. One of the teachers explained that:

"One of the main purposes is to reinforce understanding, just to make life a little bit easier. Because when we were young we were taught angle in the circle is equal to this measurement but we never understand that theory. But with technology I will show them how it works, by showing them simulation videos rotating the circle and they will have an idea".

Another participant continued saying:

"Just to build on what he said that it also enhances their understating because what they see makes them remember fast, just how they will watch a movie of the story they will be able to remember the story from A to Z".

\section{4) Provides current teaching content}

Technology makes it easy for teachers to have updated and adequate information they need to have an effective lesson. This is what one participant emphasized:

"When we talk about phones and computers connected to the internet, we get more information from the internet. We search from different websites the same information presented in different ways by different people. Searching information from the internet is better than the one in the textbooks because the information in textbooks is a little bit outdated and most of the times they are just from one person."

\subsection{Findings on Challenges Which Hinders the Introduction of ICT in Teaching and Learning}

\subsubsection{Spend on the Internet Connection}

Because of the lack or limitation of the internet, findings show that 15 teachers spend from their pockets to buy internet just to support their teaching. They spend about $\mathrm{N} \$ 40$ for AwehGig a week for data bundles on their cell phones, being explained by a participant "I spend $N \$ 40$ per week for AwehGig for the internet at my phone, since I mostly use my phone to search for my teaching materials". While some spend $\mathrm{N} \$ 350$ per month for postpaid Telecom internet, as she said:

"Because the internet does not work, some of us went on the level of having 
the internet at home, for us to search for information that will support our teaching and I pay N\$350 per month.”

\subsubsection{Spend on Printing Documents}

Printing is another service that teachers in the circuit spend on. About 7 of the participants said they spent on printing documents. Either printing test papers or making copies for learner's notes, apart from printing and making copies some teachers buy papers. It has been indicated by one of the participants saying that: "We spend a lot, for example, I buy papers if I want to print tests for my learners". And another one said, "We spend from our pockets to make copies and to print costs N\$1 per page." While the other explained that "There are times we spend $N \$ 1$ per page for printing or making copies for our learners when the copy marching in the school and at the circuit is not work".

\subsubsection{Technical Support}

Three teachers said that the lack of an IT technician to fix devices when they are damaged or broken is a problem; one of them just showed the research a staff room that had a lot of computers not working as a result of the lack of a technician to fix them. Because there is no technician to fix them, in his words he said: "in this room that we are, all those computers that you see are not working." From the researcher's observation, in that room were 30 computers and each computer had an Ethernet (internet) cable connected to it and four switches, one would think those computers are working, but real they were all not working. Another teacher explained how he was challenged when he was teaching and his computer froze.

"Just like how my laptop froze one day when I was busy teaching and I gave it to our computer teacher to help but still he could not fix it, and that just delayed my class".

The issue of IT technicians in some regions remains a challenge as some regions do not have IT technicians to support the schools and this was reported by NIED in their annual report 2015/2016. That means this problem has been recognized even by the authority in the Ministry of Education.

\subsubsection{Limited Time}

From the responses, time discourages some teachers from using technology in their teaching. One teacher stated:

"We have limited time, just to go and get a projector from the other class, set it up, get everything done, and teach within 40 minutes, you won't finish, that is why I don't integrate technology in my class and it's time-consuming".

Teachers do not want to lose their 40 minutes allocated for teaching into setting up computers and projectors and also to go around the school to look for one projector of which they might not even find. 


\subsubsection{Lack of Know-How for Learners}

"What I was thinking is, if I have pictures, videos, PowerPoints I can share them with my learners and they can use them while they are home, but my materials end with me, you use PowerPoints in class and you refer them to the textbook at home or you give them handouts."

This was stated by one of the teachers that stopped using technology because he saw it as a waste of resources if learners do not have technology at home to use them again when they are home, especially videos that cannot be converted in a hardcopy. When learners have technology at home, they can study with time the materials which are provided by their teachers.

\subsubsection{Lack of Know-How for Teachers}

From the data collected four teachers said that lack of skills and knowledge of using technology by both teachers and learners is one of the challenges they face, stated a teacher:

“As teachers, we are challenged that sometimes we don't even know how to operate a computer or to do something on your computers like editing pictures, we are challenged."

Editing pictures or just moving a cursor on a computer can be confusing and nervous especially when teachers are in front of learners. And for learners that are just seeing computers and any other technologies for the first time, it makes it very difficult for teachers to achieve their lesson's objectives. That was emphasized by one of the Computer Study teacher who said:

"Also the background of learners, they are only seeing computers for the first time, especially the ones that are coming from primary schools, I don't achieve my objectives, because learners don't even know how to use a computer; some are even scared to touch them."

While some teachers are saying that, knowledge, skills and the know-how to use technology prevented many from using technology. A mathematics teacher mentions that:

"In the mathematics syllabus, there is a topic called ICT section, but I don't know how to teach it because we were not trained on how to use the ICT section. I should do my things manually and ignore the ICT part because I don't know."

One of the participants wished he knew how to integrate technology in all the subjects she is teaching, according to her, her work could be easy, "If I had all the knowledge to put every topic in ICT probably it could have made my life easier by now."

\subsubsection{Cell Phone Stigma}

The majority of participants debated on the use of mobile phones in the class- 
room by teachers. 6 of the participants think that cellphones will be an obstacle to effective learning and do not support the use of cellphones. They said that cellphone is used for receiving calls and notifications from all sorts of social networks that can cause destruction. In the world of today where phones are addictive, it is difficult to resist a cellphone as one emphasizes "there are those temptations likes WhatsApp SMS that will come on your phone as you are teaching, that part must also be looked at." While the 9 participants are in support of the use of mobile phones in the classroom as a mode of technology, they even want a study to be conducted on the importance of cell phones in education. As one of them gave a solution of how to avoid notifications and calls, "those temptations can be dealt with at a proper management system." While the other one said, "A cell phone can be controlled; you can put it on a flight mood."

The other thing when it comes to the rules and regulations that govern the use of mobile phones in schools, teachers are scared or tend to fear to be caught or seen using mobile phones as a mode of technology by their principles or supervisors. Apart from being seen by supervisors, Teachers are also scared to be seen by their learners. Teachers are emphasizing that "even students seeing you using a cellphone in class they will go and tell their parents".

The above data testify how teachers face challenges when integrating technology in education. The data comfort [14] study's findings when she explored challenges in the integration of ICT into the teaching. Her study's findings indicated that majority of teachers could not integrate ICT because of lack of infrastructure, lack of proper training, lack of support from school management and lack of trained technicians to fixe broken resources in schools. All these berries hindered teachers to integrate ICT in teaching and learning and they will continue hindering if not successfully addressed.

\section{Discussions}

The findings indicated that teachers have a positive perception on the integration of ICT in teaching and learning. They confirmed that they know how to integrate different types of all sorts of technologies effectively in their teaching to have an interactive classroom. Every teacher has different reasons to integrate ICT into their teaching, but majority of the participants said they integrate ICT in education to make education fun and interesting. Although teachers showed that they integrate ICT into teaching and learning, there were some barriers which hinder teachers from using them as it has been emphasized by the participants. Objectives of this study were to:

To gain insight about teachers' viewpoints on how they feel about integration of all sorts of technologies into their teaching.

On the viewpoints on what teachers think about integrating technology in education, the findings indicated that teachers under the age of 40 years showed interest in integrating technology into their teaching and learning. Majority of 
the participants said that they wished to have a digitalized classroom which has smartboard and computers for every learner. Most of the participants had positive viewpoint to integrate technology in teaching and learning.

To gain insights on types the of ICT tools which are available at schools which are being used by teachers in enhancing their teaching and learning.

At least each school had ICT tools to be used to enhance teaching and learning. Every school had the following common technology such as, computer, internet and photocopy machine for teachers and learners to use. Majority of the participants stated that computers, projects, mobile phones and internet are the must have technologies in education.

To gather data on different ways on how teachers use ICT in the classroom and their reasons for using ICT.

Most teachers imply that they use technology to save time from writing on the board and taking up time for lessons by making use of PowerPoints application and a projector. Some said they use technology to expose learners to much innovative information from all over the world through the use of the internet and also to improve interaction and learning efficiency by make use of audios and videos.

Find out the main challenges faced by secondary teachers in the Kadjimi circuit when integrating ICT in teaching and learning at school.

The case studies findings showed significate number of challenges such as insufficient computers, internet and printing papers which leads teachers to spend from their own pockets without the compensation from the school. Lack of skills and training among teachers and learners were some of the challenges that discouraged teachers to use technology. There was a lack of pedagogical support from school management for teachers and IT technicians to fix broken ICT devices in schools. The finding also shows that there is a stigma around the usage of cellphones especial in the classroom during lesson time.

\section{Recommendations}

The following recommendations have been provided as a guide to tackle challenges faced in integration ICT in education and to enhance teaching and learning.

To increase the effectiveness of technology integration in education, teachers need to have regular professional development workshops [28], since teaching knowledge is increasing every given day and technology is also changing rapidly. Recommendation of a regular development will be the best approach teachers can use to learn trending technology in education. From the findings of these study and other studies of [3] [14] [20] [29], indicated that the MoE has a challenge of training teachers in ICT. Although in the ICT policy of Education under staff training stated that there will be a program planned to ensure that the training is offered to all teachers including school principals, teachers in rural 
and urban areas, staff training remains a big challenge. Since the implementation of the policy, no adequate ICT staff training has been accomplished yet. The MoE together with NIEDP can achieve staff training by adopted a method that the Kenyan government adapted, by appointing technical digital native, to support teachers as schools. They will be referred to as ICT Champions, who will be facilitating, regulating and implement ICT in schools including training staff on the job [30]. The researcher continues to suggest that, this kind of method can be implemented in phases of which the first phase must start in rural schools since ICT development is less in those areas. A proper ICT training from ICT champions who are based at schools should variety schools' management to a positive perception of ICT use in education.

\subsection{Curriculum Similarities}

"In the mathematical syllabus there is a topic called ICT section, but I don't know how to teach it because we were not trained on how to use the ICT section at university." These were words of a disturbed mathematics teacher from the study who was not well prepared to integrate technology into her mathematics class from her higher institution of learning where she gained her teaching qualification. It is the responsibility of every higher learning institution, which is training student teachers to prepare them on how to integrate ICT into their future teaching and learning practices [31]. To make this work best the researcher suggest that the Ministry of Education, higher learning institution, and schools authorities must collaborate, to come up with a strategic plan which will best prepare future teachers on how to integrate technology in every school subject. The finding indicated that currently teachers are only trained to how integrated technology in general, but not in specific subjects as it is stated in the school subject's syllabus. Moreover, participants recommended that higher institutions of learning must pay more attention on training student teachers to incorporate the use of ICT in the school curriculum when they graduate. The researcher would also recommend teachers not to rely a lot on the high learning institutes but rather train themselves, on any trending technology which is appropriate and relevant to the students and subject content.

\subsection{A Cellphone in the Classroom a Friend or a Foe}

Mobile phones are usually used as communication devices, as communication devices they serve a very potent and imperative role in academic settings [32]. But nowadays cell phones have become smarter than that, they are not just used for communication, they are used for many purposes, just like a personal computer (PC).

On the other hand, cellphone imposes a challenge on the user as it has become addictive when there is internet. Even if they are used in lesson planning and searching for educational content, at the same time cell phones can negatively affect teaching and used for the wrong purposes. That is the reason why many 
school authorities put in place rules and regulations to govern the use of cell phones in the classroom by teachers and learners.

But in the case where schools are with no adequate technologies or lack of ICT facilities, a cell phone can be considered as a critical ICT tool to be intergraded into teaching and learning. On the condition that the Ministry of Education Art and Culture collaborate with school management to establish a planned and updated policy of promoting use of cell phone integrated into classrooms [33]. The researcher suggests for a device that is of the size of a mobile phone to be developed, that will be cheaper enough for every teacher to buy. The researcher will also recommend for more research, interviews, and discussions to be conducted, as well as to describe and explore effects of integrating cellphones in the classroom in the Namibian case study.

The researcher would recommend in the future studies, researchers should consider the characteristic of the sample when selecting and recruiting participants; this should include variables such as knowledge on ITC, gender and age categories. As in agreement with what the participants have advocated for, the researcher recommends that the future study need to look at the impacts of mobile phone on teaching and learning.

\section{Conclusion}

This study described how secondary level teachers in rural schools integrate different types of technologies into teaching. The study also reported on reasons why teachers integrate different types of technologies in their classrooms and challenges that hinder teachers to use technology in their teaching and learning. From the study, it emerged that most teachers have the right attitudes and positive perceptions on the meaningful use of ICT. It became evident that participants use different types of technology not only to enhance learning but also to create an interactive atmosphere in the classroom. The study further provided suggestions on the best practices to be used by teachers at the rural areas to compensate for the lack of ICT equipment in schools; as well as how to enhance staff development and reduce negative perception about school managers for not supporting ICT at school. Finally, there was a proposal for a proper ICT training that should be implemented by ICT Champions whom the government has to appoint. The study further established that there is a need to provide all schools with adequate internet access.

\section{Conflicts of Interest}

The author declares no conflicts of interest regarding the publication of this paper.

\section{References}

[1] Buabeng-Andoh, C. (2012) Factors Influencing Teachers' Adoption and Integration of Information and Communication Technology into Teaching: A Review of the 
Literature. International Journal of Education and Development using Information and Communication Technology, 8, 136-155.

[2] Amengor, J. (2012) Integration of Technology into the Teaching of History: The Historian in Focus. Lap Lambert Academic Publishing, Saarbrücken.

[3] Ngololo, E.N. (2010) An Evaluation of the Implementation of ICT Policy for Education in Rural Namibian Schools. https://repository.up.ac.za/bitstream/handle/2263/24841/Complete.pdf?sequence $=11$

[4] Simon, W.E. and Ngololo, E.N. (2015) Teachers' Use and Integration of ICT in the Teaching of Life Science: A Case of Two Urban High Schools in Namibia. Namibia CPD Journal for Educators, 2, 51-64. http://hdl.handle.net/11070/2157

[5] Matengu, K.K. (2011) Information and Communication Technology, Innovation Education, Development: Can Adoption of ICT in Schools Assist in the War against Poverty and Underdevelopment in Namibia. Namibia Educational Research Association Journal, 11, 141-160.

[6] TechTerms (2010) Internet Terms: ICT Definition. https://techterms.com/definition/ict

[7] Yekini, N. (2014) Information Communication Technology (ICT) [Concepts and Application]. Hasfem Publication Center, Shomolu.

[8] Wise, J.B. and Ian O’Byrne, W. (2015) Social Scholars: Educators' Digital Identity Construction in Open, Online Learning Environments. Literacy Research: Theory, Method, and Practice, 64, 398-414. https://doi.org/10.1177\%2F2381336915617607

[9] Linways Team (2017) ICT Enabled Education: The Alchemy of Mixing Technology and Education. https://stories.linways.in/ict-enabled-education-d190bcc91bf0

[10] Jo, S.F. (2013) ICT in Education: A Critical Literature Review and Its Implications. International Journal of Education and Development Using Information and Communication Technology, 9, 112-125.

[11] Osakwe, J., Dlodlo, N. and Jere, N. (2017) Where Learners' and Teachers' Perceptions on Mobile Learning Meet: A Case of Namibian Secondary Schools in the Khomas Region. Technology in Society, 49, 16-30. https://doi.org/10.1016/j.techsoc.2016.12.004

[12] Amuchie, A.A (2015) Availability and Utilization of ICT Resources in Teaching and Learning in Secondary Schools in Ardo-Kola and Jalingo, Taraba State. Journal of Poverty, Investment and Development, 8, 94-100.

[13] Parvin, S. (2013) Integrations of ICT in Education Sector for the Advancement of the Developing Country: Some Challenges and Recommendations-Bangladesh Perspective. International Journal of Computer Science \& Information Technology, 5, 81-92. https://doi.org/10.5121/ijcsit.2013.5406

[14] Nuuyoma, E. (2012) Challenges Faced by English Teachers in Integrating Information and Communication Technology (ICT) in the Teaching of Reading and Writing in Two Rural Primary Schools in the Omusati Region and Four Urban Primary Schools in the Khomas Region of Namibia. Master's Thesis, University of Namibia, Windhoek. http://hdl.handle.net/11070/577

[15] Fajebe, A.A., Best, M.L. and Smyth, T.N. (2013) Is the One Laptop Per Child Enough? Viewpoints from Classroom Teachers in Rwanda. Information Technologies and International Development, 9, 29-42.

[16] Isaacs, A., Kazembe, L. and Kazondovi, C. (2018) An Evaluation of the National Information Communication and Technology (ICT) Policy at the University of Namibia in the Faculty of Education. Higher Education for the Future, 5, 104-118. 
[17] Amha Gebremedhin, M. and Fenta, A.A. (2015) Assessing Teachers' Perception on Integrating ICT in Teaching Learning Process: The Case of Adwa College. Journal of Education and Practice, 6, 114-124.

[18] Iipinge, S.M. (2010) The Integration of Information and Communication Technologies (ICTs) in the Preparation of Teachers at Colleges of Education in Namibia. Ph.D. Dissertation, University of Namibia, Windhoek.

http://hdl.handle.net/11070/476

[19] Jatileni, M. and Jatileni, C.N. (2018) Teachers' Perception on the Use of ICT in Teaching and Learning: A Case of Namibian Primary Education. Master Thesis, University of Eastern Finland, Joensuu, Kuopio.

http://urn.fi/urn:nbn:fi:uef-20181356

[20] Wilhelmina Etuna, S. (2014) Teachers Use of ICT in the Teaching of Life Science in the Khomas Region. Master's Thesis, University of Namibia, Windhoek.

http://hdl.handle.net/11070/1840

[21] Simataa, A. and Simasiku, L. (2012) An Analysis of the Management of the Namibian Information Communication Technology School Curriculum Planning History Teachers' Perception of ICT in Promoting Teaching and Learning. International Journal of Global Education, 1.

[22] Fakhteh Mahini, F., Forushanb, Z.J.A. and Haghanic, F. (2012) The Importance of Teacher's Role in Technology-Based Education. Procedia-Social and Behavioral Sciences, 46, 1614-1618. https://doi.org/10.1016/j.sbspro.2012.05.348

[23] Livia, B. (2017) What is the Role of Teachers in Modern Learning Organizations? https://blog.neolms.com/role-teacher-modern-learning-organizations/

[24] Talbot, D. (2015) The Importance of Qualitative Research and the Problem of Mass Data Gathering. https://www.linkedin.com/pulse/importance-qualitative-research-problem-mass-da ta-gathering-talbot/

[25] Del Rio-Roberts, M. (2011) How I Learned to Conduct Focus Groups. The Qualitative Report, 16, 312-315. http://www.nova.edu/ssss/QR/QR16-1/rioroberts.pdf

[26] Etikan, I., Musa, S.A. and Alkassim, R.S. (2016) Comparison of Convenience Sampling and Purposive Sampling. American Journal of Theoretical and Applied Statistics, 5, 1-4. https://doi.org/10.11648/j.ajtas.20160501.11

[27] Dilshad, R.M. and Ijaz Latif, M. (2013) Focus Group Interview as a Tool for Qualitative Research: An Analysis. Pakistan Journal of Social Sciences, 33, 191-198.

[28] Almekhlafi, A.G. and Almeqdadi, F.A. (2010) Teachers' Perceptions of Technology Integration in the United Arab Emirates School Classrooms. Educational Technology \& Society, 13, 165-175.

[29] Rejoice, Q. (2014) Principles' Perception on ICT Implementation in Secondary Schools in the Khomas Education Region, Namibia. Master's Thesis, University of Namibia, Windhoek. http://hdl.handle.net/11070/801

[30] Mwambela, C., Mondoh, H. and Thoruwa, T. (2019) Challenges in Using ICT in Teaching Secondary School Physics and Effect of Teaching Using ICT on Students' Physics Academic Achievement in Mombasa County, Kenya. Journal of Education and Practice, 10.

[31] Valcke, M., Braak, J. and Tondeur, J. (2010) Student Teachers' Thinking Processes and ICT Integration: Predictors of Prospective Teaching Behaviors with Educational Technology. Computers \& Education, 54, 103-112. https://doi.org/10.1016/j.compedu.2009.07.010 
[32] Mwilima, F. and Hangula, V. (2017) The Effects of Cell Phone Use on Academic Performance in Tertiary Education. International Journal of Law, Humanities \& Social Science, 1, 33-38.

[33] Begum, R. (2011) Prospect for Cell Phones as Instructional Tools in the EFL Classroom: A Case Study of Jahangirnagar University, Bangladesh. English Language Teaching, 4, 105-115. https://doi.org/10.5539/elt.v4n1p105 